\title{
A Study on Developing Future Scenarios in Architectural Design
}

\author{
Gizem Özkan Üstün ${ }^{1 *}$, Sena Işıklar Bengi \\ ${ }^{1}$ Department of Architecture, Faculty of Architecture, Gazi University, 06570 Ankara, Eti Mah., 5 Yükseliş Sok., Maltepe, Turkey \\ * Corresponding author, e-mail: gizem.ozkan@gazi.edu.tr
}

Received: 13 September 2019, Accepted: 08 April 2021, Published online: 31 May 2021

\begin{abstract}
The $21^{\text {st }}$ century is known for globalisation and rapid transformations in technology. These transformations also affect architecture and the urban environment. Developing projections for the future of architecture is becoming more critical in this era, where the opportunities to adapt to rapid transformations are scarce. This study investigates how to develop future perspectives for the $21^{\text {st }}$ century. Utopian speculations in the historical process and the $20^{\text {th }}$ century's Futurism movement were examined in this regard. A collective and multi-future methodology has been developed as a unique approach. In this paper, a multifuture experimental study was conducted as a daily workshop. In the workshop, seven architecture students from various universities and different architectural education years studied possible future scenarios for Beşiktaş Fish Market. Students were tasked to produce designs in compliance with the chronological timeline of the future for the possible transformation of the Beşiktaş Fish Market. The market, designed by Gökhan Avcıoğlu and GAD in 2009, was accorded the 2012 International Architecture Award and 2014 Archmarathon Crowd. In light of the outcome products obtained from the workshop, it can be stated that a multi-future way of thinking and collective production contributes to imaginative free play in the architectural design process and is a proposal to architecture as a possible preparation for the future.
\end{abstract}

\section{Keywords}

architecture, futurism, utopia, future scenarios, workshops

\section{Introduction}

Humanity has produced thoughts on fictions, dreams and the future throughout history. Harrari (2018:p.217) attributes why Homo sapiens are dominant in the world to the production of human fictions stemming from the nature of its existence. Indeed, myths, legends, dreams, and epics have been necessary intellectual fictions created throughout history. The concept of the future includes a world of fantasy that humankind has always thought about, approached with curiosity and made estimations and predictions. The formation of the future is a whole in which people think and dream about the future by evaluating the conditions of today with the experiences of the past. Thus, dreams, manuscripts and utopias designed for the future cannot be considered separately from the past and present.

It can also be argued that many of the future-oriented ideas have affected modern architecture. For example, Güzer (2000) claims that Antonio Sant'Elia's thoughts portrayed Archigram and Metabolists. It is necessary to state that technology is also a factor in this. The relationship between technology and architecture has an essential role in the formation and realisation of future ideas. While the industrialisation process in the $18^{\text {th }}$ century advanced science and technology, changes were visible in the formation processes of architecture in the following period. Kuban (1968) signifies the rapidity of this change in the $20^{\text {th }}$ century as:

"In today's world where the speed of change is hard to apprehend, the future is living in touch with today. Individuals are trying to regulate their lives into a comprehensible state with the fatigue from biological and technological changes and developments. Therefore, the intention is to bring the future to a quality that is not expected but planned. Seeing the present in terms of the developments we expect in the future means, in a sense, thinking about what future can be built upon today."

Industry 4.0 and Society 5.0 developments in the $21^{\text {st }}$ century and the rapid increase in the volume of the information network is leading to rapid changes in social structuring. 
The architecture extends to virtual spaces and is transformed. Gregotti (2016:p.66) highlights the idea of the future gaining more importance than ever in the increasingly accelerated world and that architects' future-oriented thinking is especially significant for the profession.

In this context, this study argues that architecture should focus on the idea of the future in the $21^{\text {st }}$ century, where change is accelerated in an unprecedented way, the aim being to reduce the adaptation period to a minimum.

The second part of the study comprises ways to think about the future in architecture. The futurism approach of the past and the utopian speculations encountered in the historical process are analysed. Through analysing the future projections of the $21^{\text {st }}$ century, a collective methodology was developed for thinking about the future in architectural design, and this methodology formed the fiction of experimental research in the third section.

The study aims to develop an architectural design process that inspires multi-future thinking and collectivism among architects, inspired by 'spatiotemporal' utopianism defined by Harvey (2015:p.241) as a dialectical form. In the experimental research conducted to make future speculations in architecture, semantical changes in architecture and city due to the technologies brought by the $21^{\text {st }}$ century have been analysed, and the current state analysis has been prepared in this context.

\section{Futurism and utopic speculations}

'Futurism', the internationally accepted modern art movement of the $20^{\text {th }}$ century, drove 'Futuristic Architecture' forward between 1910-1945. It is observable that speed is an inspiration in the fantasy of the future as the formation of vehicles and industrial cities such as automobiles and aircraft led to the discussion on the concept of 'speed' in the Futurism Manifesto of the Italian poet Marinetti (1909). This artistic movement rejected traditional, idealised forms, and the focus is on the idea that technology can create an urban revolution (Asim and Shree, 2018). In Antonio Sant'Elia's 'Futurist Architecture Manifesto', it is emphasised that idealised forms and traditional architectural problems are abandoned with this perspective. It aims to renovate the old by using existing technological and scientific resources as effectively as possible. In the Futuristic Architecture approach, which also rejects the perspective of continuity, the degree of being modern is defined by the metaphor of the mind. The aim is to be modern at the degree of variability of the mind (Sant'Elia, 1914). It would not be accurate to defend that architectural utopian speculations produced with the futurism movement belong only to the $20^{\text {th }}$-century modern movement; countless utopias have been encountered since antiquity.

Utopia, which involves a combination of the words 'ou' meaning 'absent/ non-existent', 'eu' meaning 'perfect', and 'topos' meaning 'place/land/country' in ancient Greek, has become more commonly used following Thomas More's novel, of the same name, published in 1516. Utopias express surreal, imaginary thoughts and desires and connotations about society, state and world order (Ekice, 2019). Numerous utopias had been built before Thomas More's first utopia and even centuries later. The transformation of humanity's dreams about the future in all of these utopias can be realised.

The Lost Atlantis continent, the Mahabharata epic, Cockaygne Realm, and the Golden Age thoughts are the most important historical elements in the formation of utopias, legends, epics and myths. 'The Sun Islands' novel thought to belong to the merchant Iambulus who lived in Ancient Greece, and Plato's novel 'The State' are examples of the literary utopias of antiquity.

It can be argued that ancient utopias introduce a reaction to the existing negativities while drawing the ideal social order (Yüksel, 2012). In the historical process, changes are also observable within utopias. Medieval and Renaissance utopias have developed cumulatively, cultivated by the past. Tomasso Campanella's the 'City of the Sun', Johannes Valentinus Andrea's 'Christianopolis', and Francis Bacon's 'New Atlantis' are seminal works that are archetypes of medieval utopias.

Thoughts about the organisation of the environment and society in which one lives are philosophically and poetically (literary) observable until the Renaissance. Renaissance is the first time that intellectual productions influenced the context of design. It can be said that the primitive samples in the field of urban design, called 'ideal urban designs of the Renaissance period', were developed through the Tratto d'arch Mtetura building by Antonio di Pietro Averlino (1400-1469). Averlino developed perspectives on an ideal city. The concept of the ideal city was picked up in designs in Alberti's (1404-1472) De re aedificatoria, the ideal military city designs of Francesco di Giorgio Martini, and city designs in Palladio's (1508-1580) I quattro libri deli Architettura are some of the examples for the ideal cities developed during the Renaissance period. One of the reasons why intellectual productions influenced the design stage in the Renaissance period was the vulnerability of city defences caused by firearms innovation and other 
technological advances, as in every period. The noticeable numerical increase in theoretical studies and their reproduction through printing presses can be considered as another reason. There is a fine line between these theoretical studies and the utopias. Architectural designs offer projections for the future. There is a transition from reality to utopia, from theoretical thoughts to ideal urban designs (Alsaç, 1978).

Etienne Louis Boulle's Newton Cenotaph (1784) and Claude Nicolas Ledoux's 'Ideal City of Chaux' can be given as examples of the $18^{\text {th }}$-century utopias. It is observed that the criticism of the problems such as excessive population growth, unhealthy conditions and inequality accompanying the industrial revolution is focused rather than the idea of a regular city in the utopias of the $19^{\text {th }}$ century. The ideal urban city of Benjamin Ward Richardson, Hygeia (1876), based on public health, and the social and architectural plans of Charles Fourier and Robert Owen, produced to eliminate the gap between the city and the countryside and to construct the existence of the society in a single 'family' structure, are examples of the utopias of the period (Yüksel, 2012).

When the studies on the future of cities throughout history are examined, it is observed that the physical / formal structure of the city is mainly taken as a reference and these studies remain at the level of reconsideration of the tangible (Akbulut, 2009). While the Italian Futurists (Futurists) of the 1900s were producing projects that highlighted technology, they developed bold ideas such as high skyscrapers and highlight streets regarding tangible urban elements (K1rc1, 2013:p.36). Utopian speculations became prominent in architectural discourse and design throughout the modernity of the 20th century and maintained their features as an experimental field for historians, theorists, philosophers and architects in the $21^{\text {st }}$ century (Contandriopoulos, 2013). The link between utopian architecture and technological development is noticeable in utopian city projects that emerged in the early $20^{\text {th }}$ century. The development of humankind, a better future and functional city formation has been qualified by the relationship architects have established between technology and utopian cities (Calisi and Vittori, 2019). Scientific and technical developments, social dynamics, wars, and environmental problems are the main factors in forming this century's utopias. The concept of dystopia, the opposite of a utopia, and their higher numbers compared to utopias also pertain to this century. A Modern Utopia (1905) by Herbert George Wells, stands out from literary utopias (Yüksel, 2012). Camillo Sitte, Ebenezer Howard, Frank Lloyd Wright, Hugh Ferris, Le Corbusier, Lebbeus Woods,
Oscar Newman, Otto Wagner, Paolo Soleri, Peter Cook, Paul Cureton, Richard Rummell, Ron Herron, Sant'Elia, Thomas Campanella, Thomas More and Tony Garnier are other names that left their mark on $20^{\text {th }}$-century futuristic approaches. Some prominent futuristic approaches and utopian speculations can be listed as follows:

- The garden city utopia in Howard's work titled Tomorrow: A Peaceful Path to Real Reform in 1898 combines the opportunities of the city with nature through the design, including a circle-shaped garden in the centre, then the public buildings around that circle, next to a central park, and then the Crystal Palace (see Fig. 1). Industrial areas were pushed to the outermost periphery, and transportation was provided by trains (Howard, 1902:p.138).

According to the architectural theorist Sant'Elia, who had $20^{\text {th }}$-century utopian city designs (Kozłowski, 2016), the curved and elliptical lines symbolise the aesthetic taste of modern people, should replace the vertical and horizontal lines used in the monumental architecture of the past. 'Perfect elegance of steel beam' and 'reinforced concrete fineness' should be preferred to the bulky appearance of marbles (Bernardo and Palmero Iglesias, 2017). Maximum flexibility and lightness should be provided by using materials such as steel, glass and brick (Asim and Shree, 2018).

In the 'Città Nuova' (New City) project, which he started work on in 1913, Sant'Elia designed a metropolis that provides remedies to the collective problems of industry and population growth (Asim and Shree, 2018). His vision was to reject buildings' individual existence and design a large, stratified, integrated, industrialised and mechanised urban structure around the city's 'life'. This idea was constructed in Città Nuova with terraces, bridges,

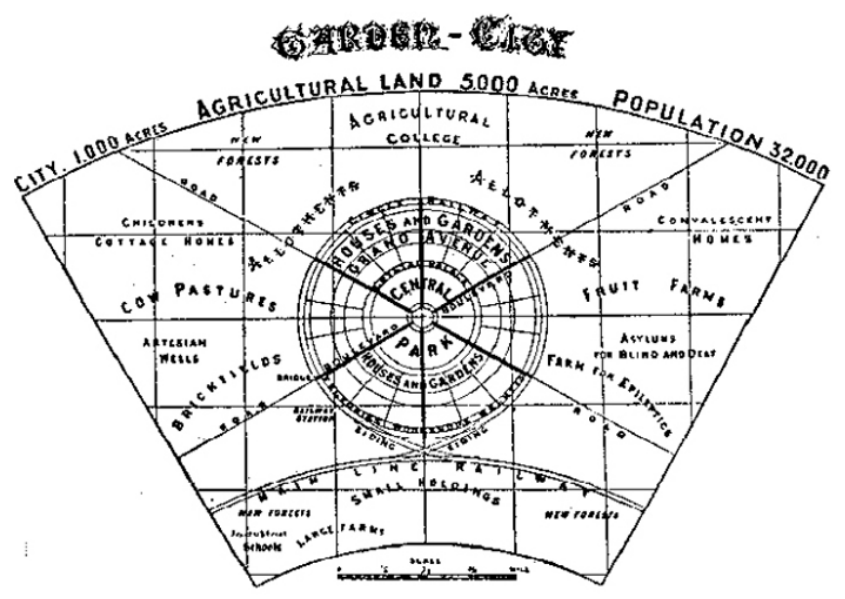

Fig. 1 Howard's garden city (Howard, 1965:p.138) 
walkways, monolithic skyscrapers, grand and multi-level traffic routes embodying modern architecture and technology (Angelidou, 2015). He exhibited the mobile and mechanical city he proposed with technological elevators, concrete, glass and steel-fed stairs on the building facades (Asim and Shree, 2018) (see Figs. 2 and 3).

Ferris introduces his ideas about a futuristic city with his publication Metropolis of Tomorrow (1929) and proposes a metropolitan representation combined with the future of science fiction (see Fig. 4). After analysing existing buildings, he presents his opinion about a futuristic city, emphasising bleak atmospheres and skyscrapers with a thick fog. The plan represents the layout of the infrastructure system and buildings in the city of the future (Calisi and Vittori, 2019). He proposes the metropolis of the future as a place that recalls the wonders of nature in a decisive formal and symbolic geometrical plan (Idzior, 2006). In planning, the city

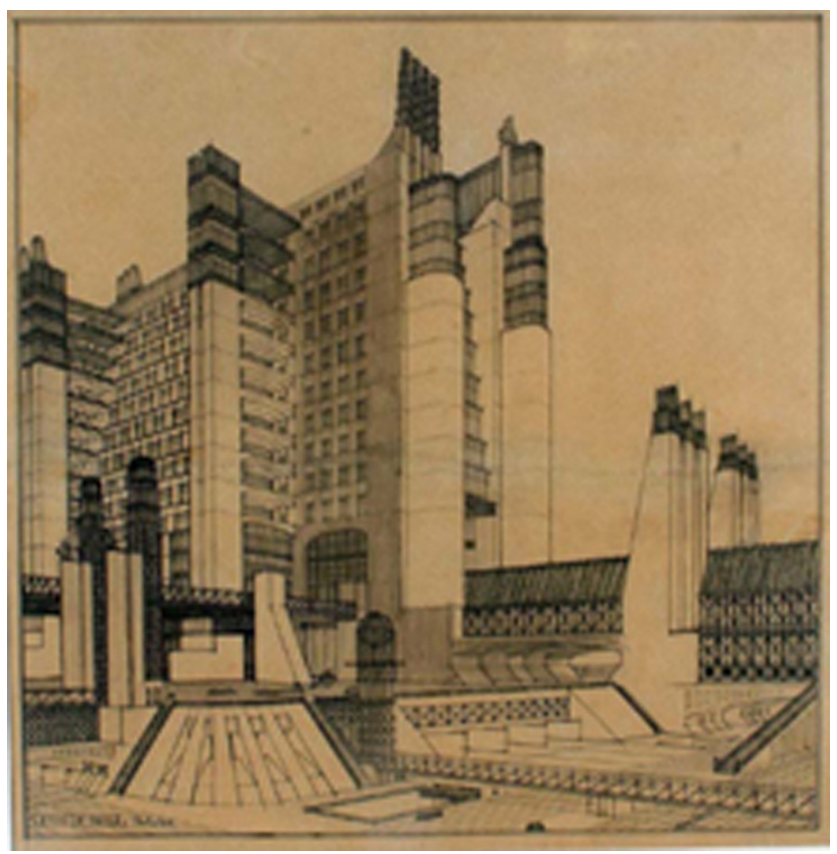

Fig. 2 Different street-level connections (Asim and Shree, 2018)

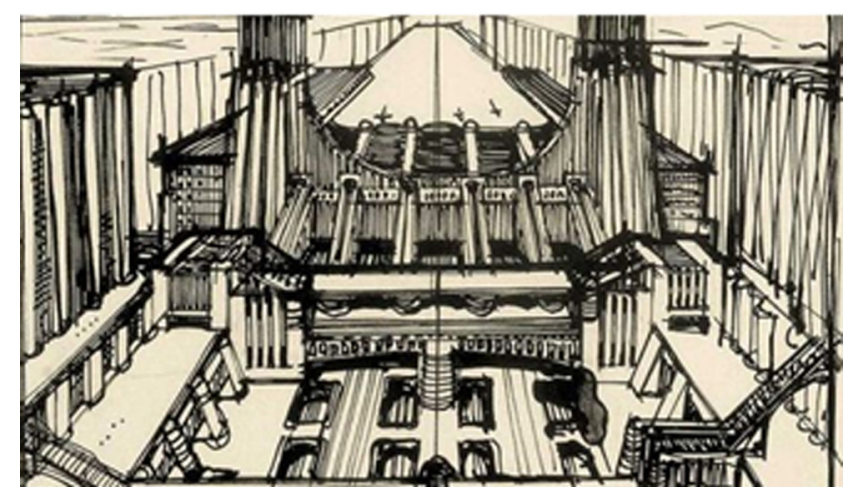

Fig. 3 The central axis of the city (McGarrigle, 2016)
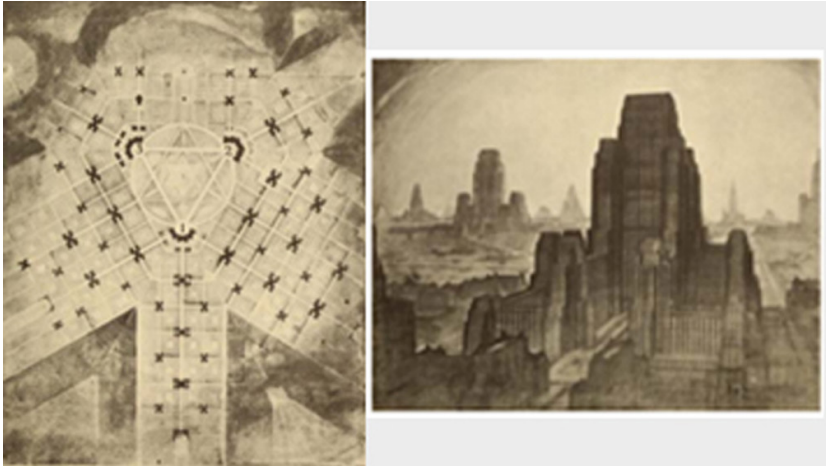

Fig. 4 Metropolis of Tomorrow (Calisi and Vittori, 2019)

is divided between several centres. These centres function as broadcast stations connected via a single network and are built on a network model. There is no central power place (Gordon, 2005). The city has three centres built for business, art and science. The business centre signifies the most significant part of the entire metropolitan area, with its tallest and closest towers that govern all the city's economic, legislative, and government activities. It consists of the main tower and eight towers connecting the four adjacent blocks next to it. The main tower buildings are black, the sub-buildings and the distribution system are white. The art centre is the artistic and cultural centre of the city. It consists of a roof that contains gardens and porches with swimming pools and trees. It was established in an area more expansive than the business centre to provide more living space. The science centre is a structure that embraces the surrounding sections and is characterised by a high central body. It is used to host science laboratories, research centres, faculties of science and engineering (Calisi and Vittori, 2019).

The Archigram is a group of names from the early 1960s, including Peter Cook, Ron Herron, Warren Chalk, Michael Webb, Dennis Crompton and David Greene. In the annual brochure titled 'Archigram' published in 1961, they specified that they thought the architecture of the period was 'reactive rather than active'. Archigram members believed that architecture was transformable and adaptable to meet the needs and desires of its users (Pickering, 2006). Plug-In City (1964), proposed by Peter Cook, an important figure associated with the Archigram, is a project that reverses the traditional perceptions of urbanism and has produced a typology that supports interchangeable infrastructure and its components as consumer needs change (Deyong, 2017) (see Fig. 5).

The futuristic, utopian speculations are just a few of the numerous utopias produced throughout history. The fact that spatial arrangements are produced in such a large number indicates 'the hope that an infinite number of 


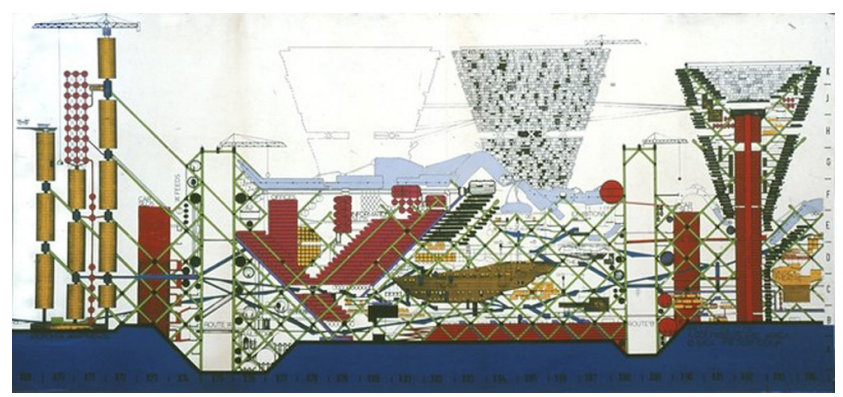

Fig. 5 Plug-In City (Merin, 2013)

social worlds are possible' (Harvey 2015:p.202). Although utopian designs can be considered an indicator of the imaginative free play and the limitlessness of imagination, the impact of authority and restrictive forms of management undermines this assessment. Therefore, utopianism was rejected in the early 2000s. Bentham's panopticon, for example, is a utopian example that creates a controlling, guardian social world (Harvey, 2015:p.202).

A panopticon is a prison built on the idea that a tower in the middle of a circular building has a viewpoint depth that can observe the walls of the circle (see Fig. 6). The windows in each cell opened along the circular walls allowing the light to reach the centre, making every cell visible. With a single observer in the central tower and prisoners' accommodation in the cells, the structure functions as a dynamic system. In this case, the logic of punishment known with the dark cell turns into punishment with the bright cell, and darkness becomes a positive state (Foucault, 1994:pp.88-97).

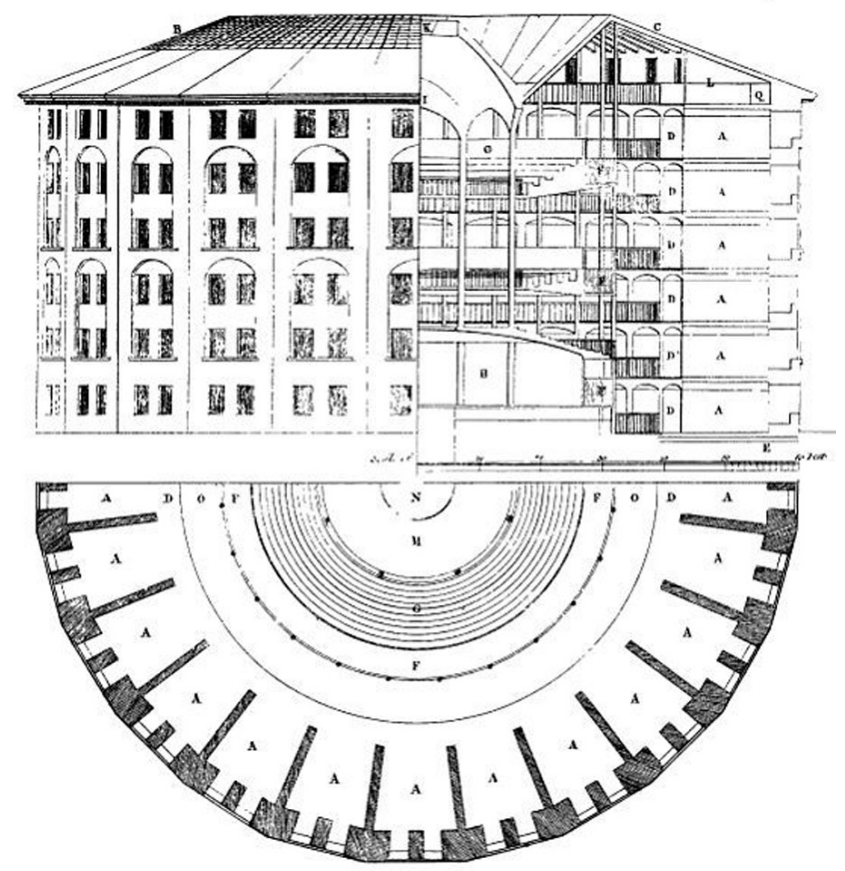

Fig. 6 Panopticon (Cutieru, 2020)
In the new period, which can be interpreted as 'the collapse of utopian forms', the idea of utopianism should not be renounced completely. Even if humankind's desire to change the world creates speculation that may remain as such, it forms seeds of the future. Strengthening utopianism can occur in a dialectical approach (spatiotemporal) through which both time and space are produced. It is necessary to redefine the limits of imagination with a different, alternative design approach by moving away from fixed and ideal forms (Harvey, 2015:p.242). In this context, it would be a repetition of previous utopian speculations in architectural design to endeavour to produce a 'perfect' form for a single point in the future that rejects the context by rigorously evaluating the current social structure and urban situation or by highlighting only the technology. The benefit of these is undeniable. However, designing multiple future times and spaces of the future can take its place as a new and original approach for the architectural design of the $21^{\text {st }}$ century.

\section{The experimental study}

The $21^{\text {st }}$-century world is experiencing a process of change with the phenomenon of globalisation caused by the cooperation between countries, and the information age phenomenon caused by the rapid development of technology. In this period, called the information age of the global environment, with the development of technology, production, use, storage, and transmission actions of scientific knowledge have reached the highest limit possible (Kaypak, 2011). Change occurs not only through the outcomes of the information age but also the global pandemics, social crises and wars. Discussing the characteristics of this rapid change is effective in making sense of the $21^{\text {st }}$ century.

In this study, a collective design process involving multiple architects and future architectures is proposed to produce an architectural design for the future by evaluating the cities' current state. It is estimated that today's analysis should be conducted to realise a future-oriented production in an urban environment or building scale and that future time should be divided into pieces and analysed step by step in connection with each other. Thus, the urban and social situation of the future scenarios shall guide the production of the architectural design of those times. The methodology developed on thinking step by step by partitioning the future will provide imaginative free play that can push the limits of imagination in architectural design. It is predicted that imaginative free play will obtain richness and dimension with the interaction caused by different architects' reflections in all future times. 
The experimental study is based on the workshop with the theme of 'Future Approaches in Architecture and Design', whichwasheldwithinthescopeofthe"Daily Workshops Series (Günlük Atölyeler Serisi / G.A.S.)", at the $3^{\text {rd }}$ International Architecture and Design Summit (3. Uluslararası Mimarlık ve Tasarım Zirvesi) (ARCH + DSGN) held on April 5-6, 2019 (ARCHDSGNSUMMIT, 2019). This workshop aimed to produce future architectural designs, an equivalent of future scenarios, on the scale of the particular buildings and urban environment to predict the $21^{\text {st }}$ century architectural and urban environment. The future scenario is based on the Besiktas Fish Market in the Besiktas district of Istanbul.

Constraints: The edited experimental study was carried out in the workshop and conducted by workshop instructors at the $3^{\text {rd }}$ International Architecture and Design Summit (ARCH + DSGN) with a participant group consisting of seven architecture students who were studying in $1^{\text {st }}, 2^{\text {nd }}, 3^{\text {rd }}$ and $4^{\text {th }}$ years in different universities. The materials are the photographs of Besiktas Fish Market, sketch papers and drawing tools.

Study Site: The $3^{\text {rd }}$ International Architecture and Design Summit (ARCH + DSGN) was held at the Istanbul Lütfi Kirdar Convention and Exhibition Center. Besiktas Fish Market, where the field study was carried out, its relationship with Besiktas Statue, its spatial scale and its public meaning were considered significant.

Designed by Gökhan Avcığlu and GAD in 2009, the project was granted the 2012 International Architecture Award and 2014 Archmarathon Crowd awards. It has a permeable and concave form. There are large openings on the facades facing the streets. The project, which aimed to cover the entire building site, provides a broad market area (GAD, 2012) (see Fig. 7).

In 2012, the municipality covered the building with signboards and canvases, which led to controversy. The plain and contemporary appearance of the building has been damaged. The final version in 2018 led to a more effective injury than the signs. The exterior of the shell was utterly painted with colourful flower paintings (see Fig. 8).

Experiment (Workshop) Setup: The workshop, which was built on developing the future scenario in Beşiktaş

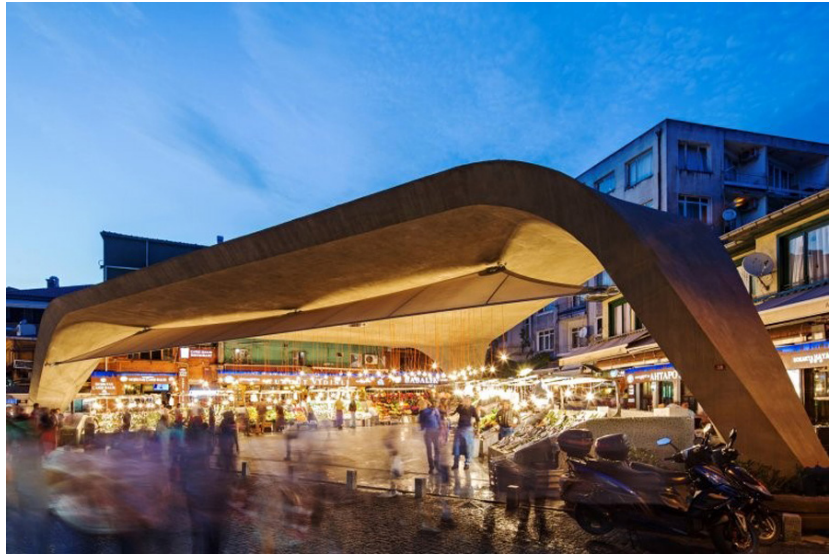

Fig. 7 Designed version of the structure (GAD, 2012)
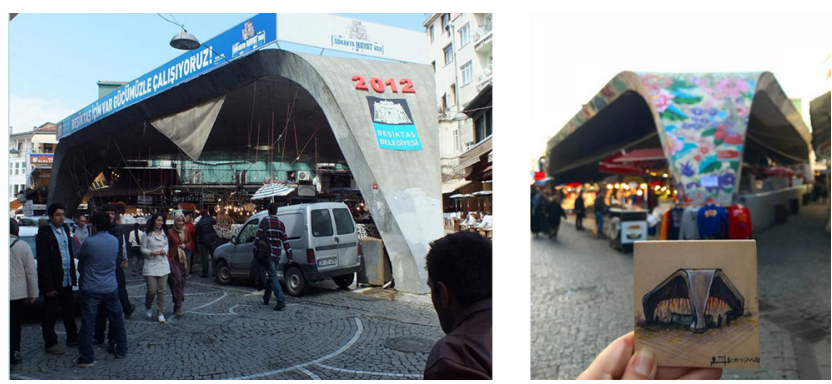

Fig. 8 Municipal intervention in the structure (Merdim, 2012); The final structure (Avcığlu, 2018)

Fish Market, used as a public area in the $21^{\text {st }}$ century, has five stages. Stage 1 was the stage of understanding and recognising the current situation/problems in the cities of the $21^{\text {st }}$ century. Phase 2 was dedicated to the exploration of location. Stage 3 was the study of conceptual ideas for a design where participants shared their experience in field surveys. Conceptual ideas produced in stage 4 were studied in the sketch environment. In the last stage, the fifth stage, presentations were made (see Fig. 9).

The workshop was to, step by step, create a future scenario targeting 2110 in a layout that developed scenarios for different future times. Each participant had to set a time for him/herself and follow what would happen regarding the city transformation before and after that time. For this reason, the workshop setup required the production of shared and individual scenarios and created a collective production process (see Fig. 10).

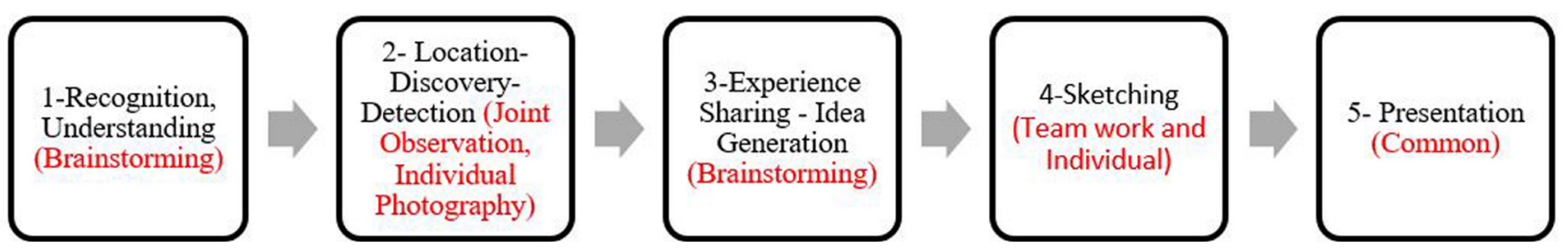

Fig. 9 Workshop fiction process 
Implementation of the Experiment: The workshop consisted of one day practice on 5 April 2019.

As the workshop time was limited, such a phase was necessary for understanding the subject and recognising the area studied. For this reason, a 15-minute interactive presentation was provided by the workshop executives to convey the changing situations, events and facts in $21^{\text {st }}$-century cities. The presentation was followed by the subject understanding and recognising phase, during which the participants created a discussion and brainstorming environment. The spatial practices that changed in 2019 were determined, and architectural programmes that could be destroyed in future periods were considered.

Following the practice of understanding and recognising the subject, a field trip to Beşiktaş Fish Market was organised. During the one-hour site exploration-detection study, it was observed that the participants met frequently and shared their thoughts. Photos of the building were taken (see Fig. 11).

After completing stage 2, the photographs taken were printed and returned to the Istanbul Lütfi Kırdar Convention and Exhibition Centre. A new discussion environment was created by sharing the experiences gained by the participants during the location exploration. To create future scenarios for the Beşiktaş Fish Market, each participant was assigned a 10-year interval within the timespan 2050 to 2110 . The process started with the participant assigned the start time design (2032), conveying the design idea to the next participant, continued with each participant producing designs related to the previous and next participant. As the design process progressed, it was observed that the final designer and the participant from the start time interacted with each other; all the participants started to think about all the times. Joint decisions were taken for the period from 2050 to 2110 , but the scenarios designs' details remained individualised. Thus, collective work emerged (see Fig. 12).

In phase 4 , the participants used the existing photographs as a base for the sketches describing their time

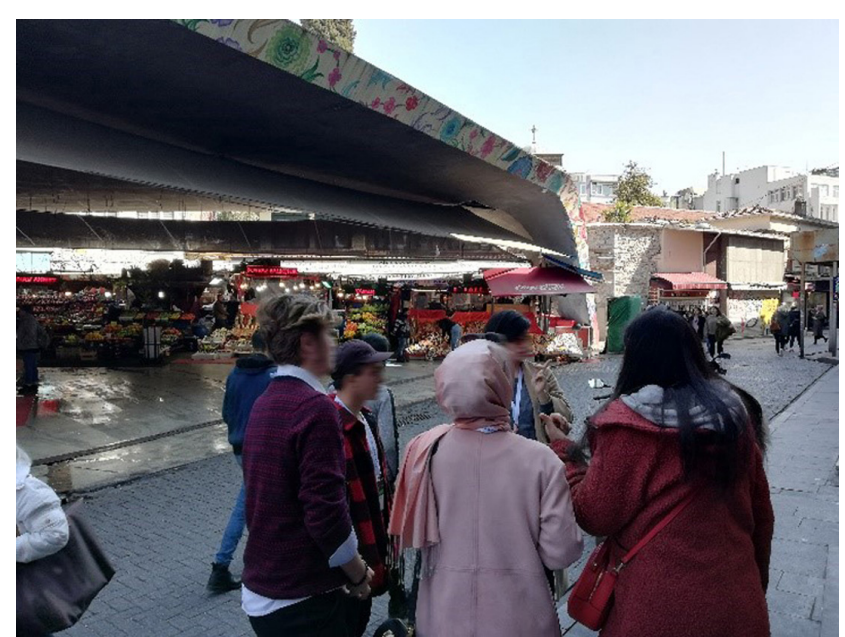

Fig. 11 Land exploration of workshop participants

interval. After 90 minutes of sketch work, the presentation phase commenced.

For the final stage of the presentation, the participants prepared a layout design that explained the sketch studies and chronological scenarios (see Fig. 13).

Findings: The start date of the participants' scenarios is 2032 when the big Istanbul earthquake is expected to take place. After this earthquake, between 2032-2050, Besiktas would be completely inundated, and the region will be re-arranged with new technologies for the development of the region.

In 2050, since there would be no land in the Beşiktaş region, new residential areas will be designed for the crowded population. Structure foundations were interpreted based on root analogy. Life units that could react to vibration and tectonic movements were designed. In addition to vertical/horizontal circulation, submarine transportation was also designed between living units. The facades of the living units' global structure consisted of screens where citizens could communicate with others.

The increasing water levels in 2060 reveal the idea of living in the water. Underwater city design includes laboratories that will carry out advanced research on human genetics. As a result of the experiments carried out in these laboratories, it is foreseen that between 2060-2070, human
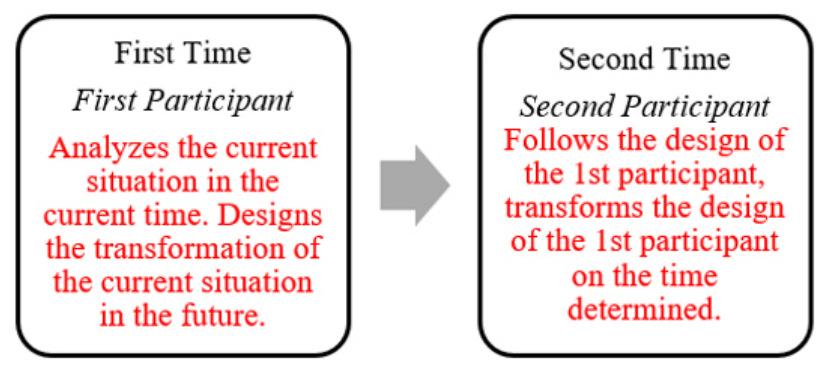

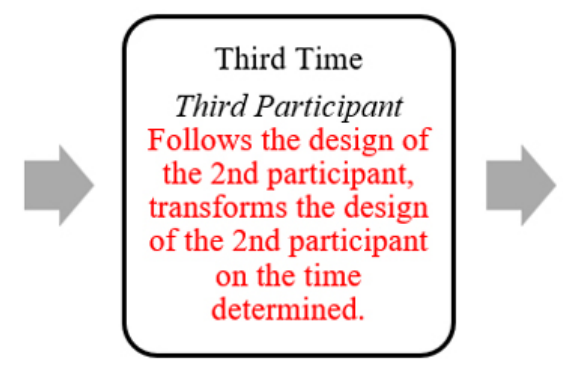

Continues according to the number of participants. 


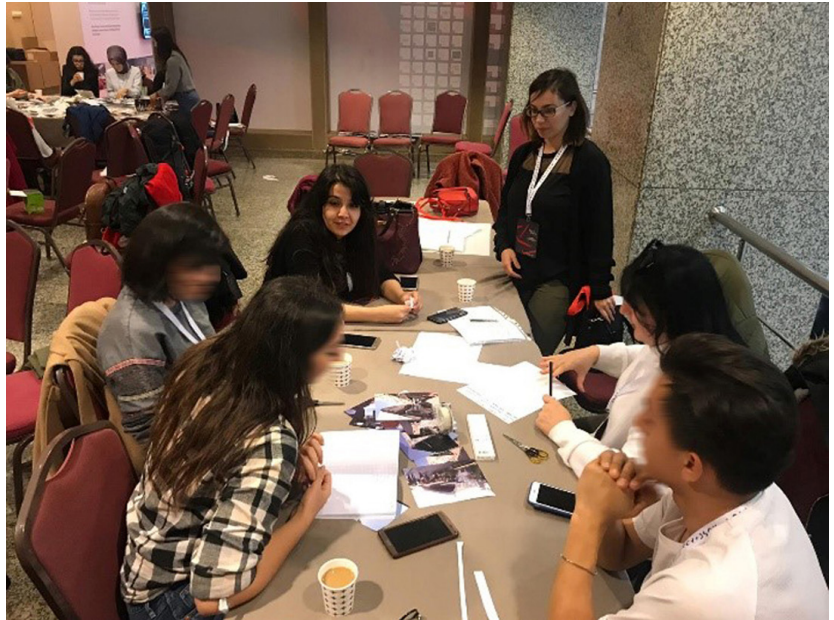

Fig. 12 Sharing the experience of workshop participants idea generation moment

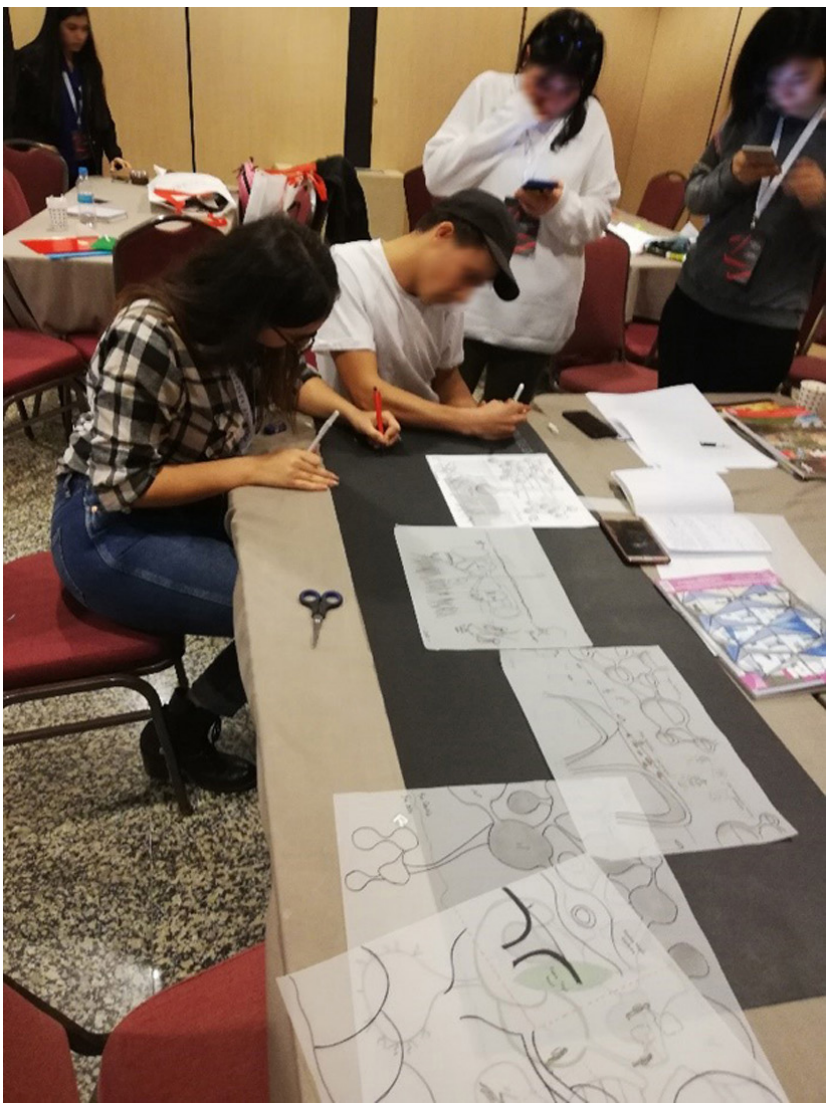

Fig. 13 Presentation moment

beings will develop a kind of gill by which they can survive underwater life. The boundaries of the underwater spaces will begin to melt, and the permeability will increase.

It was foreseen that social divisions would take place in 2070. Underwater life will become superior to land life. Aircraft will be the solution to the circulation problem that will exist between the living units on land. This situation will differentiate between the land inhabitants and the aquatic inhabitants. Communication between people will take place through screens integrated into the eye.

It was predicted that the conflict between land and underwater life would end in 2080 and that human beings will evolve. It is thought that humans who adapt to both underwater and land life will cross the threshold between water and land.

Human evolution and the transformation required would mature in 2090. The water and air capsules to be designed may be permeable or impermeable. Water and air capsules, which are integrated through flexible connections, will become important as life begins on Mars. The water needed on Mars will be supplied from these capsules.

The nano-technological weapons produced in 2100 will lead to destruction and chaos. Underwater survivors will not be affected by war.

2110 will be the period of construction activities to mitigate the effects of demolition in the short term. Custom-made designs will increase public awareness. All technological facilities will establish a city, such as ventilation systems, sunlight, agriculture and underground resources (see Fig. 14).

As a result of the experiment in this study:

1. It is observable that participants build a consensus in their speculation about the future,

2. They support their imagination in the design process through constant interaction with each other,

3. Participants think through the concepts of architecture, society, daily life together and can synthesise in building future scenarios,

4. They produce utopian designs thinking that great technological leaps will occur while they perceive the time in a dystopian state for the short-term,

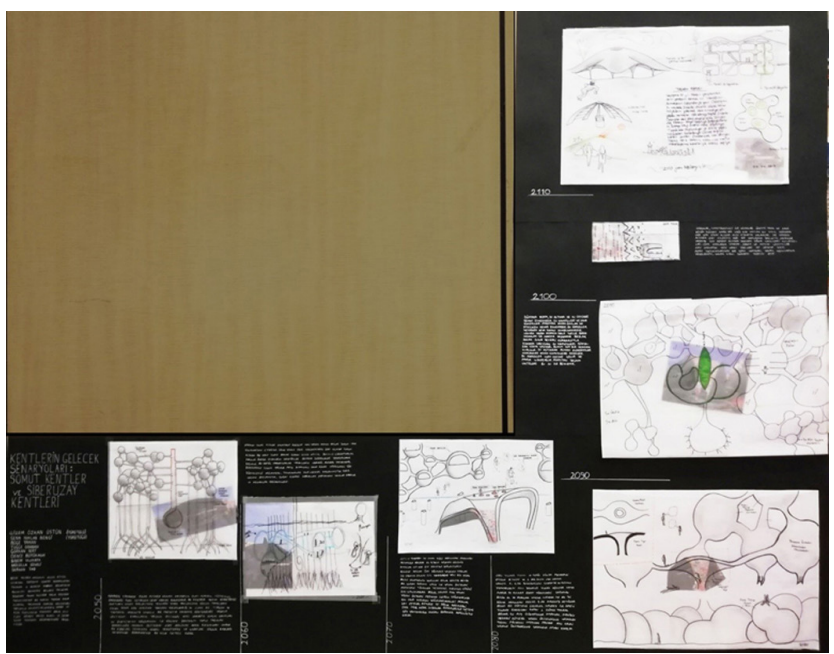

Fig. 14 Istanbul Besiktas region predictions system 
5. They try to stick to the context, desiring to preserve the production memory of Beşiktaş Fish Market despite the significant changes in the city,

6. Future scenarios are not considered separate from possible disasters considering the current situation of 2019 .

\section{Conclusion}

The $21^{\text {st }}$ century has experienced unprecedented rapid changes with technological opportunities. It is predicted that future changes will be more profound and intense than today. Humankind may not have a chance to live through a process that will allow them to stop to think and to adapt. Utopian speculations have been produced to reach the ideal, sometimes rejecting the city's context and current situation and highlighting the technology in the historical process. These futuristic approaches cumulated in a significant architecture. However, it is also possible that utopian speculations have been renounced in the new era for architectural and urban design due to restrictive results for the individual and society. In this context, not only utopian speculations but also an aspect that triggers imagination and creativity in the architectural design process is abandoned. Therefore, speculations on the future may prevent the architect from getting stuck in a static architectural design process, monotonous and drowning in the pursuit of originality while time and everyday life are rapidly transforming. Speculating about the future may lead to a discussion on the movement, variability, dynamism and richness of forms in the $21^{\text {st }}$-century architectural environment. Architects could become the visionaries of possible social and urban problems.

\section{References}

Akbulut, M. R. (2009) "21.Yüzyıl Kentleri İçin Teknolojik Kurgular" (Technology Born Fictions for the Cities of 21st Century), Tasarım+Kuram, 5(7), pp. 36-53. (in Turkish) https://doi.org/10.23835/tasarimkuram.240760

Alsaç, Ü. (1978) "Düşünsel Mimarlık: Rönesans Ütopyaları Aracılığıyla Bir Örnekleme" (Intellectual Architecture: A Sampling Through Renaissance Utopias), METU Journal of the Faculty of Architecture, 4(1), pp. 31-52. (in Turkish)

Angelidou, M. (2015) "Smart cities: A conjuncture of four forces", Cities, 47, pp. 95-106 https://doi.org/10.1016/j.cities.2015.05.004

ARCHDSGNSUMMIT (2019) "Arch+Dsgn İstanbul 2019" [online] Available at: https://archdsgnsummit.com/archdsgn-2019/ [Accessed: 09 June 2020] (in Turkish)

Asim, F., Shree, V. (2018) "A Century of Futurist Architecture: From Theory to Reality", Preprints, Article number: 2018120322. https://doi.org/10.20944/preprints201812.0322.v1
Creating a scenario in architectural design is one of the fundamental stages of almost every design process. Producing future scenarios enables it to leap beyond ideal, static formations in architecture. This study hypothesises that future architectural speculations of the new century should differ from the previous utopian conjectures inspired by Harvey's spatiotemporal dialectic emphasis. In this context, multiple times were designed, and relevant architectural solutions developed for potential problems. If architects conduct a collective architectural design process and think of multiple future scenarios in interaction with each other, they might regain the imaginative free play provided by utopian speculations. Visions and precautions for the distant future can be created by connecting the scenarios produced for the future. Hence, the experimental study carried out in this research shows that participants' simultaneously thinking of different times effectively pushes the limits of imagination, creates various and multi-dimensional problems, develops urban and architectural solutions for the problems produced, and establishes networks. This study can also be regarded as a practical example for collective and multi-dimensional thinking in architectural design problems where future speculations are not made. The authors assert that this different approach, built in the architectural design process to produce future speculations, has potential and is extendible.

\section{Acknowledgement}

We would like to thank Prof. Dr. Pınar Dinç Kalaycı for her valuable ideas on the workshop preparation process.

Avcıoğlu, G. (2018) "Beşiktaş Balık Pazarı" (Beşiktaş Fish Market), [online] Available at: http://www.instazu.com/tag/G\%C3\%B6khanAvc $\%$ C4\%B10\%C4\%9Flu [Accessed: 09 June 2020] (in Turkish)

Bernardo, G., Palmero Iglesias, L. (2017) "Architecture and materials in the first half of the 20th century in Italy", International Journal of Heritage Architecture: Studies, Repairs and Maintenance, 1(4), pp. 593-607.

https://doi.org/10.2495/HA-V1-N4-593-607

Calisi, D., Vittori, A. (2019) "Hugh Ferriss and The City of Tomorrow: from a utopic dream to a scientific and philological reconstruction", Disegnarecon, 12(23), pp. 15.1-15.16.

Contandriopoulos, C. (2013) "Architecture and Utopia in the 21st-Century", Journal of Architectural Education, 67(1), pp. 3-6. https://doi.org/10.1080/10464883.2013.771021

Cutieru, A. (2020) "The Architecture of Surveillance: The Panopticon Prison", [online] Available at: https://www.archdaily.com/937611/ the-architecture-of-surveillance-the-panopticon-prison [Accessed: 23 June 2020] 
Deyong, S. (2017) "Walking City: Archigram", In: Mallgrave, H. F. (ed.) Companion to the History of Architecture, John Wiley and Sons Inc., Hoboken, NJ, USA, pp. 1-12.

https://doi.org/10.1002/9781118887226.wbcha152

Ekice, Ş. (2019) "Heterotopyalar İçinde Bir Birey Nasıl Yaşayabilir?" (How Can an Individual Live Within Heterotopias?), IBAD Sosyal Bilimler Dergisi, Special issue, pp. 466-485. (in Turkish) https://doi.org/10.21733/ibad.612544

Foucault, M. (1994) "İktidarın Gözü" (The Eye of Power), Ayrıntı, Istanbul, Turkey. (in Turkish)

GAD (2012) "Beşiktaş Balık Pazarı" (Besiktas Fish Market) [online] Available at: https://www.gadarchitecture.com/tr/besiktas-balikpazari [Accessed: 09 June 2020] (in Turkish)

Gregotti, V. (2016) "Mimarlık Üzerine 17 Mektup" (Seventeen letters on architecture), Janus, Istanbul, Turkey. (in Turkish)

Gordon, E. (2005) "Toward a Networked Urbanism: Hugh Ferriss, Rockefeller Center, and the "Invisible Empire of the Air"", Space and Culture, 8(3), pp. 247-268. https://doi.org/10.1177/1206331205277398

Güzer, C. A. (2000) "Gerçekleşmemiş Bir Düş Olarak Mimarlık: Future Systems" (Architecture as an Unrealized Dream: Future Systems), XXI Mimarlık Kültürü Dergisi, 1(4), pp. 160-170. (in Turkish)

Harrari, Y. N. (2018) "21. Yüzy1l için 21 Ders" (21 Lessons for the 21st Century), Kolektif Kitap, İstanbul, Turkey (in Turkish)

Harvey, D. (2015) "Umut Mekânları" (Spaces of hope), Metis, Istanbul, Turkey. (in Turkish)

Howard, E. (1902) "Garden cities of tomorrow", Faber and Faber, London, UK.

Idzior, A. (2006) "Urbanotopia and the frontier in Moscow and New York at the end of the 1920s", The Journal of Architecture, 11(5), pp. 569-575.

https://doi.org/10.1080/13602360601104840

Kaypak, Ş. (2011) "Bilgi Toplumu Olma Yolunda Kentsel Değişim ve Bilgi Kentleri" (Urban Change and Knowledge Cities on the Way to Becoming an Information Society), Bilgi Ekonomisi ve Yönetimi Dergisi, 6(1), pp. 117-130. (in Turkish)
Kırc1, N. (2013) "20. Yüzyıl Mimarlığı" (20th Century Architecture), Nobel, Ankara, Turkey. (in Turkish)

Kozłowski, T. (2016) "Longing for the main street", In: Biere Arenas, R., Gyurkovich, M. (eds.) Back to the Sense of the City: International Monograph Book, Centre de Política de Sòl i Valoracions, Barcelona, Spain, pp. 97105.

Kuban, D. (1968) "Gelecek Açısından Günümüz Mimari ve Şehircilik Uygulamalarının Eleştirisi" (Criticism of today's architecture and Urbanism practices in terms of the future), Mimarlık Dergisi, 57(7), pp. 13-20. (in Turkish)

McGarrigle, N. (2016) "The Futurist world of architect Antonio Sant'Elia", [online] Available at: https://www.irishtimes.com/lifeand-style/homes-and-property/interiors/the-futurist-world-of-architect-antonio-sant-elia-1.2569429 [Accessed: 09 June 2020]

Merdim, E. (2012) "Beşiktaş Balık Pazarı'nın Başına Gelenler" (What Happened to Besiktas Fish Market), [online] Available at: http:// www.arkitera.com/haber/8991/besiktas-balik-pazarinin-basina-gelenler [Accessed: 23 June 2020] (in Turkish)

Merin, G. (2013) "AD Classics: The Plug-In City / Peter Cook, Archigram", [online] Available at: https://www.archdaily. com/399329/ad-classics-the-plug-in-city-peter-cook-archigram [Accessed: 23 June 2020]

Pickering, A. (2006) "Archigram: Architecture without Architecture", Technology and Culture, 47(3), pp. 661-663.

Sant'Elia, A. (1914) "Manifesto of Futurist Architecture", [online] Available at: https://www.readingdesign.org/manifesto-futurist [Accessed: 09 June 2020]

Yüksel, Ü. D. (2012) "Antikçağdan günümüze kent ütopyaları" (Urban utopias from antiquity to the present), İdealkent, 3(5), pp. 8-37. (in Turkish) 